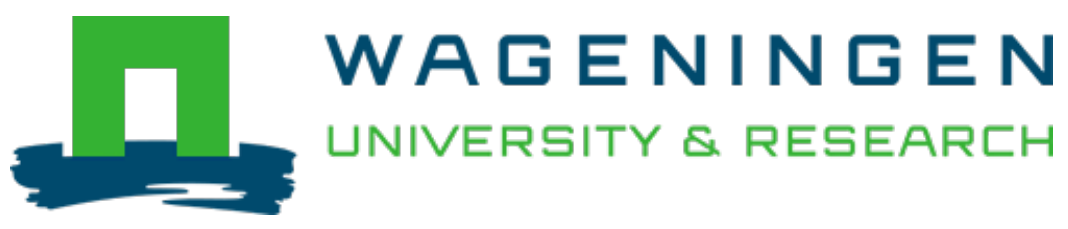

\author{
Reassembling nature and culture: Resourceful farming in Araponga, Brazil \\ Journal of Rural Studies \\ Berg, Leonardo; Roep, Dirk; Hebinck, Paul; Teixeira, Heitor Mancini \\ https://doi.org/10.1016/j.jrurstud.2018.01.008
}

This article is made publicly available in the institutional repository of Wageningen University and Research, under the terms of article $25 \mathrm{fa}$ of the Dutch Copyright Act, also known as the Amendment Taverne. This has been done with explicit consent by the author.

Article $25 \mathrm{fa}$ states that the author of a short scientific work funded either wholly or partially by Dutch public funds is entitled to make that work publicly available for no consideration following a reasonable period of time after the work was first published, provided that clear reference is made to the source of the first publication of the work.

This publication is distributed under The Association of Universities in the Netherlands (VSNU) 'Article $25 \mathrm{fa}$

implementation' project. In this project research outputs of researchers employed by Dutch Universities that comply with the legal requirements of Article $25 \mathrm{fa}$ of the Dutch Copyright Act are distributed online and free of cost or other barriers in institutional repositories. Research outputs are distributed six months after their first online publication in the original published version and with proper attribution to the source of the original publication.

You are permitted to download and use the publication for personal purposes. All rights remain with the author(s) and / or copyright owner(s) of this work. Any use of the publication or parts of it other than authorised under article $25 \mathrm{fa}$ of the Dutch Copyright act is prohibited. Wageningen University \& Research and the author(s) of this publication shall not be held responsible or liable for any damages resulting from your (re)use of this publication.

For questions regarding the public availability of this article please contact openscience.library@wur.nl 


\title{
Reassembling nature and culture: Resourceful farming in Araponga, Brazil
}

\author{
Leonardo van den Berg*, Dirk Roep, Paul Hebinck, Heitor Mancini Teixeira
}

\begin{abstract}
A B S T R A C T
This article highlights the emergence of a regenerative, agroecological mode of agriculture following the ongoing process of experimentation and learning by a settlement of landless people and farm workers. It examines how they engaged anew with 'nature' and generated resourceful farming practices as a result of a threefold process of cultural re-appreciation, a re-grounding in local natural resources and a political-economic re-positioning towards prevailing regimes in policies, markets and technologies. We argue that the construction of resourceful farming culminates around: finding and forging productive alignments with non-human nature such as weeds, trees and mychorrizal fungi, viewing the contribution of non-human nature not only in terms of their value as a commodity, but as adding value in many different ways and building a socio-material resource base and an institutional setting that allows farmers to farm more autonomously.
\end{abstract}

\section{Introduction}

It has been widely argued amongst scholars that de-agrarianisation and agricultural degradation result from the commodification of land and labour, and the simplification and rationalisation of agriculture, which breaks the metabolic relationship between 'nature' and 'culture' in agriculture. In the literature, this is referred to as the 'metabolic rift' (Marx, 1973; Foster, 1999; Wittman, 2009) and has been taken as a defining feature of the capitolocene, the era in which extraction of nature has and is irreversibly destroying the planet on a geological timescale (Moore, 2017). It is argued that the metabolic rift can only be repaired through transformations of the larger state economy and that (agroecological) alternatives function as a form of capitalism "from below" that only works well in ecosystems rich of natural resources. Such alternatives, it has been further argued, will not be able to produce enough to "feed the world" and require a large amount of labour because they are devoid of external knowledge, technology and inputs which disables farmers to make a decent living and drive the younger generation away from agriculture (Jansen, 2015; Bernstein, 2014).

These arguments carry problematic assumptions about the relation between human 'culture' and non-human 'nature' in farming. First of all, non-human nature is taken as either décor that can be ignored or as a resource that can be technically controlled and fixed by its "natural" characteristics. Such a view ignores the non-human labour force upon which agriculture rests, such as mycorrhizal fungi and soil organic matter, making it de facto invisible, often with overexploitation and degradation as a result (Tsing, 2015; Martinez-Alier, 2002). Ignoring the agency of non-humans next to those of humans disregards the productive potential of human and non-humans alignments in different time-space constellations. Second, the valuable contribution of nonhumans in farming is reduced to the "objectified" exchange value or price of the commodities produced. In doing this, farming is reduced to the transformation of markets based inputs, with commodities such as seeds and fertilizers, into other commodities. This leaves farming being embedded in and determined by the logic of commodity markets (van der Ploeg, 2010; Schneider and McMichael, 2010). This view obscures non-market transactions and the versatile benefits farming may bring to the agro-ecosystem, the livelihoods of farmers and their communities and society as a whole (Martinez-Alier, 2002; McMichael, 2013). And third, it disqualifies the culture of farming, and more in particular a peasant style of farming (Van der Ploeg, 2013), as a being pre-capitalist, outdated, inefficient and inherently inert. Thus ignoring the inspirational, creative and innovative power of culture in general, as in arts, and the art of farming in particular. Culture refers to shared ideas, notions, norms and values shaping the social (inter)actions of humans, as well as an interaction with non-humans in a meaningful way. It includes an appreciation of these interactions and what are seen as good farming practices in aligning culture and nature, and how by mediation of farming techniques cultural and natural processes get assembled into and are co-evolving as part of an agro-ecosystem.

In this article we present a detailed account of how 'nature-culture' alignments are reworked and how culture, nature and technology are re-assembled in a settlement of previously landless people and farm workers in Araponga, Brazil. How they, in becoming farmers, developed resourceful, place-specific farm practices, seen as key to a peasant mode of farming (Van der Ploeg, 2013, 2017). Earlier this has been presented as a case of repeasantisation and - in view of their return to the land and quest for land - also a case of reagrarianisation (Van den

\footnotetext{
* Corresponding author.

E-mail address: leonardo.vandenberg@gmail.com (L. van den Berg).
} 
Berg et al., 2016). In an evolving process of collaborative experimentation and learning-by-doing the farming community developed the space and the capacity to reshape 'nature - culture' interactions and develop more resourceful, agroecological farming practices - notably, in an area where the natural resources had been degenerated because of commodity-based, agro-industrial farming practices. Their shift towards and commitment to agroecological, regenerative farming practices was given crucial support by change agents and agencies, complemented by new institutional arrangements and effective institutional reform (Van den Berg et al., 2016). In this article we continue to argue how this process of re-alignment and re-assembling can be analysed as an evolving, threefold process of a re-appreciation of farming and good farming practices, a re-grounding of farming in the available natural resources with the intention to enrich their resource base, that however has to complemented by a re-positioning towards prevailing markets, policies and innovation systems to create a more supportive institutional embedding to their resourceful, regenerative farming practices.

In section two of the article we will first frame the development of resourceful, regenerative farming as re-assembling nature and culture, arguing that we cannot think of them as entities on its own, they are coconstructed and co-evolve, intermediated by farming techniques. Next the methodology is briefly explained in section 3. Section four of the article provides a detailed account for the Araponga case, followed by a discussion and conclusion.

\section{Resourceful farming: re-assembling 'nature-culture' in a threefold process}

If we want to understand how 'nature-culture' alignments are reworked in developing resourceful farming practices, we first of all need to go beyond the dichotomy of 'nature' versus 'culture' in which both are conceptualised as two separate, bounded entities or 'orders', e.g. as an ecosystem and a social system, that exist on their own each with its own distinct dynamics (Ingold, 1993; Jasanoff, 2004). We must also move away from linear explanations of nature as determined by culture (Haraway, 1991; Norgaard, 1994).

For a better understanding we have to move away from perceiving nature and culture as fixed relationships or as bounded entities towards an understanding of socio-material assemblages that encompass both natures and cultures and that are constituted by ideas, human and nonhuman agents, acknowledging that agency is distributed amongst both human and non-human agents (Deleuze and Guattari, 1987; Haraway, 1991; Anderson and MacFarlane, 2011; Woods, 2015).

Ordering results from temporary alignments of ideas, human and non-human agents (Law, 1994; Muller and Schurr, 2016) which may be local or from other localities (Tsing, 2000; Davies, 2012; McFarlane, 2009). 'Nature' and 'culture' can thus only be distinguished analytically. 'Nature' can be reconsidered as all living and dead matter, a material dimension resulting from the alignment between human and non-human agents. 'Culture' refers to the shared ideas, notions, norms and values shaping the (inter)actions of human beings, resulting in patterns of shared ways of doing, thinking and feeling as cultural repertoires or styles of farming (Van der Ploeg, 2012). Nature-culture alignments are not politically neutral. They incorporate particular actively constructed values and views, which are embedded in particular power constellations that in turn can intervene in and impact on natureculture alignments (Latour, 1983; Mol, 1999). Next to natural (or ecological) and cultural ordering processes, we thus acknowledge for the political-ecological dimension.

Agents may deliberately rework nature-culture interactions by intervening in socio-material assemblages and try to intermingle or reorder them. This may result in intended, unintended and even unforeseen outcomes that re-align agents or that lead them to disperse and reassemble in a new constellation (Davies, 2012; Muller and Schurr, 2016). To understand interventions we therefore have to think of a complex working whole in which nature and culture are seamlessly interwoven (Roep, 2000).

Human interventions have been divided into those that seek to control nature and those that resemble notions of "living with" nature. The latter entails a more responsive and responsible relation to nonhuman nature (Hinchliffe, 2008; Pickering, 2008; Turnhout et al., 2013). Human interventions can enrich, maintain or degrade places. Roep et al. (2015) and Horlings (2016) maintain that an enrichment of places involves a well-coordinated, threefold process of cultural re-appreciation, of re-grounding in natural resources and a political-economic re-positioning towards prevailing regimes in policies, markets and technologies. Resourceful, regenerative farming can be conceptualised as an expression of such a threefold process.

Farming practices can be understood as deliberate interventions by human agents in an effort to coordinate a complex assemblage constituted by specific seeds, plants, animals, soil, fields, landscapes, buildings, machines, humans, farms, families, industries, consumers but also shared ideas, norms, values and so on that according to the ability of the practitioners are aligned in specific and productive ways, resulting in time- and space-differentiated, place-specific, intended, unintended and even unforeseen outcomes (Tsing, 2000; Buller, 2013). This is what Van der Ploeg $(2013,2017)$ denotes as 'the art of farming'.

Different farm assemblages can be seen to represent different values, depending on how the assemblage is constituted. One can think of two contrasting modes of agriculture. One mode extracts (valuable) resources from the place of production and transfers them to the place of consumption. This is associated with an agro-industrial mode of farming and has been heavily promoted under the Green Revolution. The transfer of resources and accumulation in the place of consumption provokes a degradation of resources and impoverishment in the place of production. The agroecological mode of farming counters this. It aims to enrich the resource base at the place of production, creating multiple values to the benefit of farmers, their families, their livelihoods, their community and the agroecosystem they operate in (McMichael, 2013; Turnhout et al., 2013). In short: enrich the place. The first mode is a commodity directed agriculture, also referred to as a capitalist or entrepreneurial mode of farming, and the contrasting second mode is commonly referred to as a peasant mode of farming (see Van der Ploeg in this special issue; McMichael, 2015).

Following this, one can imagine a shift from a commodity based mode of agriculture that is merely extracting value from a place, to a versatile mode of agriculture that add multiple values to a place, enriching the resource base and thus has the potential to counter the degeneration and depletion of resources and the consequent impoverishment of livelihoods, communities and places. The Araponga case provides a telling example of the emergence of a place-enriching, regenerative agriculture. This involves a well-coordinated, threefold process of re-appreciation, re-grounding and re-positioning: a re-appreciation of farming and the agroecosystem it operates in and a quest for farming practices that will generate a multiplicity of values for the place; a re-grounding of farming in the agroecosystem that aims to enrich the socio-material resource base, i.e. both natural and human resources; and a re-positioning towards prevailing regimes in policies, markets and technologies that promote and support a commodity-orientated, agro-industrial mode of farming. All include a transformation of power relations and a re-assembling to create the space and build the capacity to farm differently, re-working the complex whole of ordering processes.

\section{Methodology}

This paper draws from an ethnographic study carried out in the municipality of Araponga, in the Zona da Mata region in Brazil, which has been considered an exemplary case of agroecology (Cardoso and Mendes, 2015). It combines data derived from oral histories, farm observations and documented reports. The research draws on 25 interviews that enabled to reconstruct the process through which farms 
changed from a more Green Revolution type of farming to agroecological farming.

Although the study includes people that worked for the NGO, the Federal University of Viçosa and the Arapongan Rural workers union, which initiated programmes to support the change from Green Revolution to agroecological farming, most of the interviews were conducted with farmers including their experiences of these programmes. Three months were spend in Araponga where contacts were established to undertake interviewing and farm observations. Care was taken to select farmers that had been both more and less involved in official programmes as well as to ensure a balance in gender and age.

To understand how nature-culture alignments were reworked and resourceful farming was developed, interview transcripts and documents were first used to reconstruct the histories of farms and farmers including how programmes that promoted agroecology entered the farm assemblage. These were then analysed to identify alignments between human and non-human agents that were created and abandoned on the farm and how this involved a simultaneous, threefold process of cultural re-appreciation, ecological re-grounding and political-economic re-positioning.

\section{Resourceful farming in Araponga: a threefold process of re- appreciation, re-grounding and re-positioning}

\subsection{Agriculture in the zona da mata and in Araponga}

The Zona da Mata comprises an area of about $36000 \mathrm{~km}^{2}$ and lies in the Atlantic Rainforest in the southeast of the state of Minas Gerais (Fig. 1). Most of the land in the Zona da Mata is owned by landlords and a newly emerging class of agro-industrial corporations. Farm workers, sharecroppers, and smallholder farmers also rely on the land for their livelihoods. They are amongst the poorest of the groups in the region. Sharecroppers rent land from landlords in exchange for part of the harvest. The cost of inputs such as chemical fertilisers is often also shared between the landlord and the sharecropper. Like sharecroppers, rural workers do not own land. They are hired by rural estates to work as day labourers and are often hired to perform a specific task, such as harvesting, weeding or pruning. Smallholder farmers own small pieces of land. However, these three categories are not mutually exclusive. Smallholders often also engage in sharecropping and/or work as rural workers during the harvesting season. Similarly, landless sharecroppers often also work as day labourers.

From the early 1960s onwards the Brazilian Institute for Coffee and the government Organisation of Technical Assistance and Rural Extension Services (EMATER) promoted the 'Green Revolution' in the state of Minas Gerais. Their objective was to spur economic growth in the region by modernising and commercialising agriculture. Most interventions were directed at the production of coffee, which was seen as the most profitable cash crop in the region. Interventions provided financial incentives to remove low producing coffee trees and to plant new ones (Nabuco, 1990) as well as agricultural advice and rural credit under the condition that a package of Green Revolution technologies and prescriptions was used (Gomes, 1986).

Through the Green Revolution chemical fertilisers, lime and agrotoxins became part of farm assemblages in the Zona da Mata. Farms were directed at production of coffee under prescriptions that were the same for the whole of Brazil; indifferent to its diverse regions and types of farmers (Gomes, 1986). Coffee was to be produced as monocrop, under full sun and with a fixed, prescribed spacing between the plants. Weeds but also maize and beans, which were often planted in between

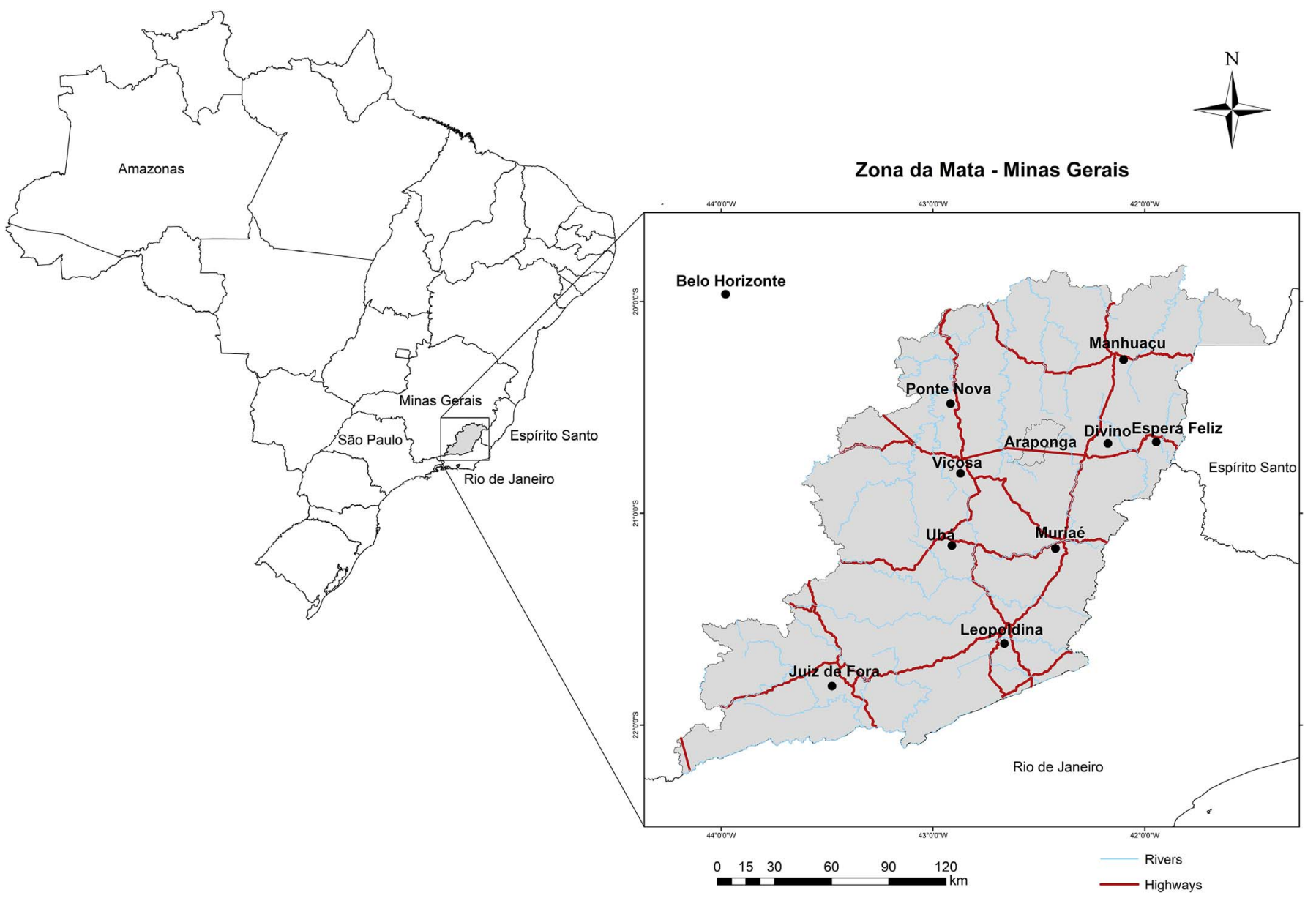

Fig. 1. Map of Brazil and of the Zona da Mata in Minas Gerais. 
the coffee, were removed. The planting food crops on other plots, also a common practice amongst sharecroppers and smallholders in the region, was discouraged and became less common. Food, it was said, could be bought from the earnings generated by growing coffee instead of growing it oneself. Landlords often forbade sharecroppers to plant food crops.

Although the Green Revolution led to short-term increases in coffee production it also led to biodiversity loss, soil erosion, deforestation, the pollution and depletion of water sources and indebtedness amongst farmers (Cardoso et al., 2001; Fernandes et al., 2005; Cardoso and Mendes, 2015).

As the Green Revolution gained ground, a movement that would later counter the Green Revolution, began to take shape amongst sharecroppers and farmworkers in the Zona da Mata region. In the 1970's farm workers and sharecroppers organised themselves in Base Ecclesial Communities (CEB), small groups consisting of 5-20 neighbouring families. The groups held meetings that were self-organised and led by lay leaders. Members would pray and sing at the meetings, but they would also engage in politically oriented readings of biblical texts, informed by liberation theology. The idea of the CEB came from the 1965 Conferência Nacional dos Bispos do Brasil which had at the time embraced liberation theology. Araponga, a small municipality in the Zona da Mata region (Fig. 1), hosted several CEB groups.

Araponga is a small municipality in the Zona da Mata region. According to a census, the number of inhabitants in the municipality in 2010 was 8152 of which $62,69 \%$ lived in the rural areas (IBGE, 2006). Araponga covers an area of $304.4 \mathrm{~km}^{2}$ and is located $50 \mathrm{~km}$ from Viçosa, $280 \mathrm{~km}$ from Belo Horizonte and $378 \mathrm{~km}$ from Rio de Janeiro (see Fig. 1). The area has been characterised as inclined and with soils that are generally of low fertility (Valverde, 1958). Over $92 \%$ of the farms are owned by family farmers ${ }^{1}$ who together occupy $60 \%$ of the farm area and who have an average farm size of 8.1 ha (Table 1).

Over $90 \%$ of the farms in Araponga produce and sell coffee. According to an agricultural census that took place in 2006 (IBGE, 2006) most of the agricultural land in Araponga is under coffee and pasture, which are also responsible for most of the agricultural income generated in the region (Table 2). The majority of family farms also produce other crops including beans, maize, cassava, rice, sugarcane, legumes, fruits and vegetables which are consumed by the family or sold locally (Campos, 2014). This has not been accounted for by the census.

Between 1996 and 2006 the number of farms smaller than 50ha increased from 544 to 1.358. This was in part due to the Arapongan land conquest movement through which rural workers and sharecroppers purchased land (Campos, 2014).

The origins of Arapongan land conquest movement can be traced back to the CEB. The CEBs made their entry in Araponga in the 1980s and introduced critical ideas from liberation theology. During meetings sharecroppers and farm workers jointly reflected on these ideas and discussed how they related to their everyday lives. This led them to problematize their relation to their landlords. They received only half of the harvest and had to do all the physical work. They also had no say over what crops to grow and how to grow them. Sharecroppers began to perceive this as a form of inequality and injustice. Through the CEB meetings and readings, members also began to embrace notions of equality, unity and solidarity between 'poor' families and their neighbours.

To tackle these newly perceived injustices the Arapongan Rural Workers' Union (STR) was founded in 1989. The STR offered support to its members by drafting sharecropping agreement contracts for them,

\footnotetext{
${ }^{1}$ Family farms have been defined by the Brazilian national law $n^{\circ} 11.326 / 2006$. The law states that family farms undertake economic activities in rural areas, earn below a maximum set income, use family labour for their activities, and generate income from land and family based activities.
}

Table 1

Characteristics of farming in Araponga.

Source: IBGE (2006).

\begin{tabular}{ll}
\hline Property & value \\
\hline Number of farms & 1412 \\
Total farm area (ha) & 17751 \\
Number of family farms (\%) & 92.6 \\
Area of family farms (\%) & 60.0 \\
Average farm size of non-family farms (ha) & 68.2 \\
Average farm size of family farms & 8.1
\end{tabular}

Table 2

Properties of some agricultural activities in Araponga.

Source: IBGE (2006).

\begin{tabular}{ll}
\hline Property & Value \\
\hline Area of forest (\%) & 21.3 \\
Area of pasture (\%) & 43.1 \\
Area of coffee (\%) & 31.2 \\
Percentage of farms selling coffee & 91.5 \\
Income from coffee (thousand reais) & 16655 \\
Percentage of farms selling milk & 12.8 \\
Income from milk (thousand reais) & 630 \\
Percentage of farms selling maize and beans & 36.5 \\
Income from maize and beans (thousand reais) & 432 \\
\hline
\end{tabular}

by offering legal support when there was a dispute with a landlord and, later, also helped smallholder farmers to acquire legal property titles for their land. While the union was being set up, however, sharecroppers and rural workers realised that this would not be enough. They would still be dependent on landlords and continue to lead a restricted life under their control. It was within this context that the Land Conquest Movement arose.

The Land Conquest Movement comprised groups of sharecroppers and rural workers who pooled their resources to collectively purchase land. Between 1989 and 2010, 161 sharecroppers and workers purchased land, comprising an area of over 700 ha. (Campos, 2006). The average purchase size was 6 ha per farmer. The movement also attracted Arapongans who had migrated to live in the slums of São Paulo or Rio de Janeiro. They returned to Araponga to purchase land and make a living as a farmer.

Although land offered these new farmers a new-found freedom from their landlords, they soon encountered another problem. Much of the land they had purchased was degraded. Some of the land was degraded to the extent that coffee would no longer grow there. Before selling the land, landowners had cultivated pasture without appropriate management, leading to a scarcity of resources and production:

There was no coffee tree, not a single tree. So we were on land that was ours. We had all the autonomy but no production. João, Arapongan farmer

Farmers also saw how their monoculture-based farming practices were further degrading land and leading to a decline in production. They feared that by continuing to farm in accordance with Green Revolution practices, they would jeopardise the future of their farms.

Another group that was concerned with the Green Revolution was the Viçosa Alternative Agriculture Group (GAAV). The GAAV was founded by a group of students from the Federal University of Viçosa (UFV) who were interested in agroecology. ${ }^{2}$ Together with another group, named ALFA, they established a garden to experiment with alternative farming practices, started a restaurant that served organic meals, organised discussions and participated in congresses on

\footnotetext{
${ }^{2}$ At the time, the term 'alternative agriculture' was used. From about 1999, onwards alternative agriculture was renamed agroecology.
} 
alternative agriculture. They noticed, however, that they were reaching only a small number of farmers, and with little impact. They came up with the idea of creating a small, locally situated and practically oriented research centre. In 1987, they founded the Centre of Alternative Technologies of the Zona da Mata (CTA-ZM) together with 13 rural worker unions in the Zona da Mata. The CTA-ZM now operates in more than 10 municipalities of the Zona da Mata where the Rural Workers' unions are active. This includes the municipality of Araponga. Together with the Federal University of Viçosa, farmers' organisations and CTAZM started a trajectory of collaboration that continues today.

In the beginning, the alliance promoted farming practices that they themselves had identified as sustainable. However, they soon realised that by working in this way technicians predefined the problems and solutions for farmers (Cardoso and Ferrari, 2006; Cardoso and Mendes, 2015). The methodology and the indicators that researchers and technicians used for monitoring project impact were, for instance, not seen to reflect the way in which farmers saw success (Cardoso and Ferrari, 2006). They then shifted their focus from promoting technologies to facilitating processes with groups of farmers in order to collectively explore problems they were facing and define actions to be taken. During these processes, scientific methods were questioned by, and adapted or redeveloped with the help of, farmers.

One of the first interventions facilitated by the agroecology alliance took place in 1993 in Araponga, in response to a request from the Arapongan Farmers' Union that farmers be given an opportunity to explore their problems. Meetings were organised in which participating farmers mapped and prioritised the challenges they were facing. Topics included soil degradation, the health effects of chemical pesticides and insecure land rights. According to the CTA-ZM farmers were the ones that explained the problem to staff members rather than the other way around. Farmers were the ones to remark that 'the soil was weak'. This was picked up by the NGO staff and led to the establishment of the Terra Forte (strong soil) committee (Cardoso et al., 2001; CTA-ZM, 2005). As this and other interventions evolved, farmers in the Zona da Mata came to recognise the alliance as a legitimate and capable actor in addressing the problems they faced (Cardoso and Mendes, 2015).

\subsection{Weeds for a 'strong soil'}

Farms in Araponga were suffering from land degradation. Ploughing, which was done to control weeds, left the soil bare and loose, and therefore prone to erosion. Soil erosion was leading to significant reductions in coffee yields and led Arapongan farmers and the Arapongan Rural Workers Union to declare soil erosion as the most urgent problems they were facing. Through the Terra Forte committee new alignments were formed between farmers, the farmers union, the CTA and the UFV to address the problem of soil erosion.

To find and devise solutions to counter soil erosion they first had to politically reposition themselves towards prevailing innovation systems. They had to challenge the Green Revolution. including the view that weeds are always competitors for water, light and nutrients, and therefore have to be completely removed. They also had to create a protected space to reflect upon alternative ideas, experiment with alternative practices and develop alternative, agroecological knowledge. New practices were developed and tested via on-farm experiments; many were based on aligning coffee and weeds.

These practices ecologically re-grounded farming by reassembling the farm to encompass weeds. Weeds were no longer seen as competitors of coffee but as producers of soil cover and organic matter. Three practices that became widespread in Araponga were selective weeding, mulching and cover cropping. With selective weeding farmers ploughed under or pulled out only those weed types that they had actually observed to have negative effects on the crop. The other weeds were chopped. The roots were deliberately left intact so that they continued to hold the soil and the chopped-off part was left as a mulch to cover the soil. These practices protected the soil from erosion and over time the weeds also became producers of organic matter, which helped to make the soil more fertile. ${ }^{3}$ With cover cropping, farmers deliberately planted vegetation to cover the soil. Some cover crops, including mucuna, feijão guandu, calopogônio and crotalaria were also used as green manures which help to fix nitrogen in the soil, thus improving its quality. Measurements found reductions in soil erosion from 2611.9 to up to $217.3 \mathrm{~kg}$ of soil per hectare per year when practices to protect erosion were combined in Araponga (De Souza, 2006).

Practices were also developed to re-generate degraded lands. These were mostly used on soils that would no longer produce coffee or other crops. On these soils farmers allowed spontaneous vegetation to grow or planted a specific sequence and combination of vegetation. This vegetation would be chopped down and incorporated into the soil. After some time organic matter builds up in the soil make it more fertile. By restoring degraded lands in these ways, some farmers were able to convert degraded pasture lands into productive areas for maize, coffee and other crops (Mendonça and Stott, 2003).

The subsoil was shallow, I had to manage it with vegetation for seven years before I was able to plant coffee. [...] I planted different types of vegetation. So that roots could penetrate the soil. So that they open the soil. And create pores for water to enter, for organic matter to enter. For organic matter to turn into humus. So that the soil fattens a bit and enables me to plant coffee. João, Arapongan farmer

Part of the process of developing solutions against soil erosion was a cultural re-appreciation of farmers' own resources and of the resources they could produce themselves. This is also visible in the Ten Commandments (Table 3), a set of principles drafted by the core group of the Land Conquest Movement in 1995. Although the purpose of Ten Commandments was to avoid opportunistic behaviour within the Land Conquest Movement, affinity with agroecology is evident in commandments 1, 3, 8, 9 and 10 which emphasise the importance of appreciating own resources and relations of trust.

Non-human nature also came to be culturally re-appreciated as a potential with which productive alignments could be forged with the farm. Farmers, and other actors, became more observant of, and responsive to, non-human nature. Agroecology provided a loose framework in which farmers could position these experiences and observations (Botelho et al., 2016). This was important to find new, productive alignments between nature and farming.

It is not just agroecology. It is agroecology based on various details. These details are present in everyday life and work. You can see them. When you are working you see: "Hey this needs to be improved. Let me search for a specie that allows me to solve this problem." You just have to work in the area and you'll see all this details. You will be modifying or improving the farm every day. João, Arapongan farmer.

\subsection{Letting the forest in}

Once they had managed to halt soil erosion many farmers in Araponga ran into a new challenge. The price of chemical fertilisers was increasing while the price of coffee remained the same. This was putting pressure on the net income of farmers.

All the money comes from the coffee. And then, depending on how much money you have made, you have to return all the money to the coffee again, in the form of chemical fertiliser. Maria, Arapongan farmer

The price of coffee is stable but the costs of fertiliser increased. So it ends up that he who produces coffee gains less. Those who continue this habit will have a serious problem. Samuel, Arapongan farmer

Many farmers sought to offset this effect by working harder - by

\footnotetext{
${ }^{3}$ Farmers also valued these practices because they consider chopping weeds using a scythe to be lighter work than ploughing weeds under using a hoe.
} 
Table 3

The 10 commandments in the joint land conquest movement.

Source: CTA-ZM (2002: 26)

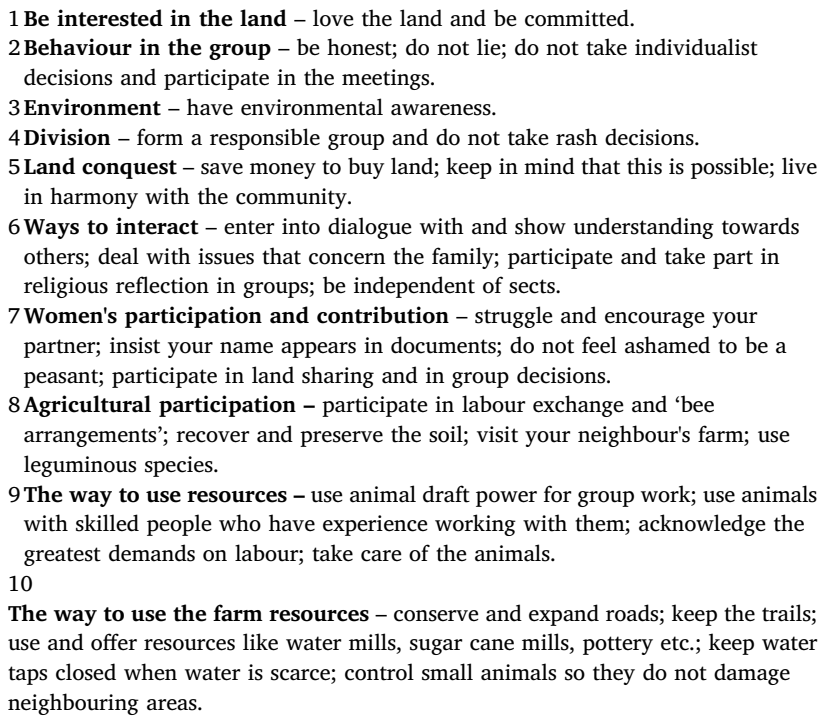

9 The way to use resources - use animal draft power for group work; use animals with skilled people who have experience working with them; acknowledge the greatest demands on labour; take care of the animals.

10

The way to use the farm resources - conserve and expand roads; keep the trails; use and offer resources like water mills, sugar cane mills, pottery etc.; keep water taps closed when water is scarce; control small animals so they do not damage neighbouring areas.

putting more effort into pruning or weeding, for example. These efforts, however, took a lot of time, taking away their freedom to do other things. Some farmers also began to apply lower amounts of chemical fertilisers, and got caught in a negative spiral. Less fertiliser led to lower yields and coffee earnings, leaving these farmers with even less money to buy fertiliser for the season after. Aware that world phosphate reserves were diminishing, farmers thought it unlikely that fertiliser prices would drop again. In this context, farmers began to question their dependency on these commodity markets. At the time growing trees in the coffee fields had already been experimented with as a measure to reduce erosion, now farmers and NGO staff wanted to explore the potential of trees to provide nutrients and reduce their dependency on chemical fertilisers.

Again, the Green Revolution was challenged and agriculture was politically repositioned when the CTA, UFV and Rural Workers' Unions aligned to start the participatory agroforestry systems programme in 1994, which created a new space for alternative knowledge and practices on trees and coffee to be developed. Similar to weeds, farmers, informed by the Green Revolution, used to see trees primarily as competitors for water, nutrients and light. For the efficient production of coffee, trees, and any other plants besides the coffee, were always removed. Trees were also seen as breaking up the neat rows in which the coffee was planted, therefore affecting the efficiency with which fields could be weeded and coffee harvested and pruned. In the agroforestry programme trees were seen as a productive resource and between 1994 and 1997, 39 agroforestry experiments involving 33 family farmers in 11 municipalities took place (Gjorup et al., 2004; CTA-ZM, 2005). Over 70 species of trees were experimented with.

To allow for the exploration and discovery of positive alignments between trees and coffee cultivation the programme was set up as a learning process that put the observations and experiences of farmers central in selecting, rejecting, designing, experimenting with, evaluating, and fine-tuning solutions (Cardoso et al, 2001; Botelho et al., 2016). Through the experiments farmers for instance observed how different species competed with coffee, produced different amounts of organic matter and needed different amounts of labour to be maintained. On the basis of these experiences desirable species and traits were identified to further experiment with.

In the end Araponga farmers further re-grounded agriculture in the local ecology by finding new productive alignments between coffee, trees and microorganisms. These alignments allowed new flows of nutrients and organic matter to enter the farm. Now, instead of removing vegetation from the coffee fields, farmers in Araponga were actively letting the forest in. Many trees grew spontaneously, others were planted or seeded by the farmers. Farmers came to plant different tree species and varieties in order to deliver a range of nutrients to the coffee (Duarte et al., 2013). They planted varieties such as fedegoso (Senna macranthera), ingá (Inga sp.), jacarandá-branco (Plathypodium elegans) and garapa (Apuleia leiocarpa), because of their capacity to derive desirable nutrients from various sources. One of these sources is the air from which leguminous trees capture nitrogen. Another nutrient source is the deeper layers of soil. Farmers thus used deep-rooting tree species to tap nutrients from these layers. A final source is the phosphorus that is strongly bound to the soil and is considered to be unavailable for the coffee. Farmers accessed these nutrients by managing tree varieties that host mycorrhizal fungi. The fungi are able to adsorb strongly bound phosphorus and exchange this with carbon compounds produced by the tree. The nutrients the trees capture are stored within the tree itself (Cardoso and Kuyper, 2006; Cardoso et al., 2003). Farmers harvested these nutrients by pruning the branches of these trees or by waiting until the tree lost its leaves naturally. They timed the moment of pruning carefully, or selected varieties that lose their leaves at the time when the coffee needs nutrients the most. Micro-organisms plays an important role in converting nutrients in the leaves into forms that can be used by coffee plants. Some farmers began to protect or tried to enhance the population of microorganisms. For many, this was an extra reason to diminish the use of chemical fertiliser, which has harmful effects on microorganisms. Other trees such as Inga (Inga sp.) brought in natural enemies that control pests such as the coffee leaf miner (Rezende et al., 2014) and the coffee berry borer (Moreira, 2012), reducing the necessity to apply chemical pesticides.

Through the alignment between trees and coffee farmers were able to reduce their dependency on chemical fertilisers (Duerte et al., 2013; Mendonca and Stott, 2003), enabling them to economically re-position their farm vis a vis commodity markets and farm more autonomously.

The cultural re-appreciation of trees also led farmers to plant and experiment with trees on their own accord, outside the agroforestry programme. Farmers obtained saplings from neighbouring forests or forest fragments, as well as from family and from colleagues in the CEB and began to manage and protect some of the trees that emerged in the field spontaneously (Martins, 2007). Some farmers began to undertake their own experiments, some with successful results. One of these aligned trees and other vegetation with streams that ran through the farm. Many of these streams had run dry or had almost dried over the time of one generation. The trees and vegetation planted, transformed the soil so that it could hold more water. As a result, more water was found flowing in the streams. Some streams that used to run dry for part of the year now also have a more continuous flow. Farmers used this new water for drinking, as well as for their crops and livestock (Ferrari et al., 2010).

Other experiments initiated by farmers include finding different trees that allow for the survival of microorganisms throughout the year. Microorganisms were found to play an important role in making flows of nutrients generated by the trees available to the coffee. Many of these microorganisms live in leaf residues. To ensure that a large population of microorganisms survive throughout the entire year, some farmers planted trees that lose their leaves at different times of the year (De Souza et al., 2010). This was done to ensure that there was always a leaf layer covering the soil for microorganisms to live in or feed from. One farmer began to collect microorganisms from the forest and added them to his coffee field. This was done by applying a layer of leaf litter from the forest onto the coffee fields.

During these experiments many farmers also discovered that next to delivering nutrients, trees produced other values. Farmers valued the new landscape that trees produced - certain varieties were planted specifically to make the landscape more beautiful. They also valued the shade of the trees when working in the fields and the fact that the trees 
protect the coffee from rain and wind storms. Many farmers also valued the wildlife that the trees host:

Haha, with all these trees birds no longer go to the nature reserve but come to my property instead. Domingo, Arapongan farmer

\section{4. 'We need food crops, we don't need coffee'}

Next to their dependency on chemical fertilisers farmers were also struggling with the rising price of food in the local supermarkets.

When the coffee price drops, they say it breaks your right arm. Because people don't have anything else. They have no maize, no beans. Neusa, Arapongan farmer

Prior to the Green Revolution most farmers in the Zona da Mata region had planted food crops in addition to coffee. The Green Revolution discouraged this on the basis that it was more efficient to specialise in coffee and buy food on the market from the coffee earnings. To cope with increasing food prices farmers in Araponga bought less vegetable and fruit. Their diets came to consist mostly of rice and other staples. However, as periods of hunger and illness became more frequent, farmers began to challenge how they had become dependent on coffee to buy their food:

Many of the people said that no wealth can be created with food crops. And that coffee should be grown instead. But this is a proposition with which I totally disagree. We need food crops, which is maize, beans and rice. We don't need coffee. Afonso, Arapongan farmer

Farmers began to re-position themselves vis a vis commodity markets by producing their own food. Food crops made their entry in various parts of the farm. One of these was the coffee field and was taken up by the agroforestry programme. Farmers cultivated avocados, bananas, prunes, citrus, papaya and peach trees in the coffee fields. For many, the coffee fields became an important source of fruit which was sometimes processed. Some farmers made soap from avocado; others used it as a major source of pig feed, which allowed them to keep a larger number of pigs. Fourteen varieties of leguminous trees were also used for animal feed; seven varieties became a source of construction wood; eight leguminous tree varieties were also used as a source of firewood; five yielded wood to construct fences and four were used for wood to build ox-drawn wagons. In addition, farmers harvested parts that are used for medicinal purposes from six varieties (Martins, 2007; De Souza et al., 2010).

Another space for food production was the lavoura branca field. In the past, these fields reserved for the production of arable food crops were common in the region. However, lavoura branca declined with the advent of the Green Revolution. Farmers in Araponga re-established lavoura branca fields where they cultivated maize, beans, potatoes and cassava, thus producing a large part of their families' staple diet themselves. Some of these crops were also processed. Sugarcane was processed into the raw sugar derivatives açucar mascavo and rapadura. Cassava and maize were processed into flours and into the starch derivatives, amido de milho and fécula de mandioca. These all form important ingredients for dishes and pastries that are typical in the region.

The home gardens were another part on the farm where food production took place and which farmers strengthened. These gardens became the most important source of vegetables for Arapongan farmers. In addition to this, many farmers started to keep more small livestock around the house. Chicken were kept for their meat and eggs, pigs for meat. Pig fat was used as an alternative to cooking oil and also to conserve meat. Animal production was integrated into the rest of the farm activities. Farmers' self-produced maize, vegetable remainders and fruits formed important sources of feed for the animals. The manure of the animals was in turn used as a fertiliser.

A final area which farmers put to use were the forests neighbouring the farm and forest patches inside the farm. They harvested parts from the species Solidago chilensis, Ageratum conyzoides for medicinal purposes. They also harvested edible wild plants: Portulaca oleracea, Amaranthus deflexus and Emilia sonchifolia. These varieties are especially eaten in times of drought, when the production of other crops is low (Souto, 2006). These same species were also protected and managed by the farmer when they emerged spontaneously as weeds in the coffee field and other cultivated areas. Management does not necessarily entail planting, but selected weeding, or removing parts of the plant to prevent it from spreading and interfering with the coffee plant.

Farmers re-appreciated their own food not only because of its value as a commodity, or of not having to buy a commodity, but also as a way to provide the family with food and freedom:

Coffee has made a lot of money for some people but it has also impoverished many. That is why we work with agroecology, you work with diversity within your property. You are not dependent on only one product, you have more security. You don't need a lot of money to buy things from outside. You don't get into a lot of debt when you are not only dependent on coffee. If the dollar appreciates, if the dollar depreciates, we will not be hungry. Samuel, Arapongan farmer

Another value was health and family. Many farmers in Araponga began to produce and eat more, and a larger diversity of, fruits and vegetables. These foods were appreciated for their high nutritious values. Some farmers produced a surplus of vegetables to ensure that family members in the city would also have healthy food. A further value was the maintenance of labour exchange relations. Patches of sugarcane were planted in the coffee fields. These patches were not for the family or the market. They served as a 'snack' that was consumed during the breaks when fellow farmers came to help with harvesting or weeding the coffee. Certain foods, such as cream cheese, were produced only to be given as a gift to other farmers.

\subsection{Labour exchange, collectives, and new markets}

The re-positioning of farming vis a vis commodity markets to create farm autonomy occurred not only through the production of own food an inputs but also by constructing nested markets (Van der Ploeg et al., 2012; Hebinck et al., 2015) and by re-discovering forms of social exchange based on reciprocity (Sabourin, 2017).

Some of the new farming practices in Araponga demanded more labour from the farmers. One way in which farmers dealt with this was by creating new alignments with other farmers through troca de dias, a labour exchange scheme that had almost disappeared in the region. Troca de dias became especially popular for the harvesting of coffee. Through this reciprocal practice, a farmer receives help from a group of farmers and returns the favour by helping each of the other farmers when it was their turn to harvest. Troca de dias allows all the coffee to be harvested at once which in turn enabled farmers to dry and roast all their coffee at once. Troca de dias was not only valued for the labour it provides but also as a way to maintain and deepen friendships. Many farmers also mentioned that there is more 'joy' in working together and began to use troca de dias for planting and weeding coffee and arable food crops, in addition to harvesting.

Other collective initiatives that operates on the basis of trust was the construction and management of a small artisanal sugar mill and the foundation of a small organic coffee cooperative, through which farmers pool their resources to hire a truck and jointly sell their coffee to a large cooperative in the more distant city of Novo Resende, a cooperative that buys organic coffee from farmers for a higher price.

Farmers also began to make new alignments between food crops, the Arapongan farmers association (AFA) and citizens through the creation of a small farmers' shop, the mercadinho, that established in the centre of the municipality by the AFA. The association provided a building for the shop as well as a shop attendant for free. In the shop Arapongan farmers sell their produce directly to consumers. It is the farmers' responsibility to bring their produce to the shop, i.e. the shop 
does not buy the produce from the farmer. The shop now sells maize, beans, potatoes, yams and coffee. In addition, vegetables such as lettuce and cabbage, and fruits such as avocados and bananas are sold, as well as foods that farmers have processed such as sugar, cheese, cassava flour and maize flour. Farmers value the shop because no contract is needed, the goods can be dropped off at any time and they can sell a whole variety of products. This works well with the diversified production of their farms and enables them to sell any surplus they have.

When you are able to get things directly from producer to consumer, both gain. Because you can sell for more while the consumer pays less. Unfortunately it is usually the middlemen that take the largest share. Samuel, Arapongan farmer

An open farmers' market was also established: held once a week in the urban part of the municipality, it sold similar products to those sold in the farmers' shop. New alignments were also create with the school. AFA mobilised a group of farmers to take part in the national school feeding programme in 2010. Through this programme schools buy part of their ingredients to make school meals directly from farmers in the municipality. Alignments were also made with citizens in Vicosa when AFA, the CTA, the UFV and farmer organisations in other municipalities created the Rede Raizes da Mata, an open market in Viçosa that sources directly from a network of farmers in neighbouring municipalities.

Small groups of farmers also constructed markets themselves. A group of three farmers, for example, began to deliver potatoes and yams to people that live in the municipality. They delivered them on horseback or on motorbikes to people who had placed an order. Usually large orders were made. Another type of exchange that small groups undertook was a kind of barter trade. Neighbouring families would agree that one of them would specialise in growing a particular vegetable or bean type, while the other family would cultivate something else. After harvest, farmers would exchange vegetables and beans. This practice is valued both because it saves the family labour and because it maintains or strengthens bonds with other families.

\section{Conclusion}

This article demonstrates how reassembling of nature-culture alignments, through threefold processes of re-appreciation, regrounding and re-positioning, can give rise to a regenerative, agroecological mode of agriculture or resourceful farming. In Araponga local natural resources, and biodiversity were re-appreciated. Farming was re-grounded in local agroecosystems and these were regenerated and enriched by strengthening soils and enhancing biodiversity. Repositioning occurred through the creation of new, innovative arrangements and relations around knowledge, technology, markets and policy.

The construction of agroecological, resourceful farming, or processes of re-appreciation, re-grouding and re-positioning, culminate, for one, around finding and forging productive nature-culture alignments. The case of Araponga shows how farms were reassembled to incorporate productive alignments with weeds, trees, mycorrhizal fungi, natural enemies and microorganisms that allowed new flows of nutrients, organic matter and water to enter the farm, and which in turn countered soil erosion, regenerated degraded lands and enabled farmers to produce a wider array of crops. Finding productive nature-culture alignments involves rejecting the view of non-human nature as a resource that is fixed by specific characteristics and that can be controlled by universal technologies and prescriptions. Instead, the agency of nonhuman nature must be recognised. This involves creating more (agro) ecological ways of understanding non-human agents such as the soil, weeds and trees, as well as valuing (farmers') experiential knowledge and observations. In Araponga this occurred at the collective level where farmers, NGO staff and researchers engaged in a joint process of exploration, learning and reflection.

The construction of resourceful farming also requires viewing, and ceasing, the valuable contribution of non-human nature not only in terms of their value as a commodity, but as adding value, or having the capacity to do so, in many different ways. The case of Araponga shows how new nature-culture alignments generated outputs based on other values such as diverse and healthy foods, a beautiful landscape, friendship with fellow farmers, shade of trees to work in, etc. Finally, resourceful farming culminated in the construction of a socio-material resource base and an institutional setting that allowed farmers to farm more autonomously. By cultivating and processing their own food and by constructing nested markets (Hebinck et al., 2015), farmers distanced themselves from global commodity markets, giving them more room to make changes to their farms. Through alignments with CTA, UFV and the Arapongan farmers' union an institutional setting was created that allows for and stimulates the further development of resourceful, agroecological farming and nested markets.

\section{References}

Anderson, B., McFarlane, C., 2011. Assemblage and geography. Area 43, 124-127.

Bernstein, 2014. Food sovereignty via the peasant way: a sceptical view. J. Peasant Stud. 41 (6), 1031-1063.

Botelho, M.I., Cardoso, I.M., Otsuki, K., 2016. "I made a pact with God, with nature and with myself': exploring deep agroecology. Agroecol. Sustainable Food Syst. 40 (2), $116-131$.

Buller, H., 2013. Individuation, the mass and farm animals. Theory, Cult. Soc. 30 (7/8), $155-175$.

Campos, A., 2006. Conquista de terras em conjunto: redes sociais e confianca: A experiencia dos agricultures e agricultoras familiares de Araponga. MSc thesis. Universidade Federal de Viçosa, Viçosa.

Campos, A., 2014. Redes sociais, organizacoes e politicas publicas: interfaces na agricultura do municipio de Araponga, Zona da Mata de Minas Gerais. Unpublished PhD Thesis. Rural Sociology. Federal University of Rio de Janeiro: Rio de Janeiro.

Cardoso, I., Mendes, F., 2015. People managing landscapes: agroecology and social processes. In: agroecology for Food Security and Nutrition. In: Proceedings of the FAO International Symposium. FAO, Rome.

Cardoso, I., Ferrari, E., 2006. Construindo o conhecimento agroecológico: trajetória de interação entre ONG, universidade e organizações de agricultores. Agriculturas 3 (4), 28-33.

Cardoso, I., Kuyper, T., 2006. Mycorrhizas and tropical soil fertility. Agric. Ecosyst. Environ. 116, 72-84. http://dx.doi.org/10.1016/j.agee.2006.03.011.

Cardoso, I., Van der Meer, P., Oenema, O., Janssen, B., Kuyper, T., 2003. Analysis of phosphorus by 31PNMR in Oxisols under agroforestry and conventional coffee systems in Brazil. Geoderma 112, 51-70. http://dx.doi.org/10.1016/S0016-7061(02) 00293-8.

Cardoso, I., Guijt, I., Franco, F.S., Carvalho, A., Ferreira Neto, P., 2001. Continual Learning for Agroforestry System Design, vol. 69. University, NGO and farmer partnership in Minas Gerais, Brazil. Agricultural Systems, pp. 235-257 2.

CTA-ZM, 2002. Revista CTA-ZM 15 Anos. Viçosa MG).

CTA-ZM, 2005. Sistematização das experiencias com sistemas agroflorestais do CTA/ZM. CTA-ZM. Viçosa).

Davies, A., 2012. Assemblage and social movements: tibet support groups and the spatialities of political organisation. Trans. Inst. Br. Geogr. 37, 273-286.

Deleuze, G., Guattari, F., 1987. A Thousand Plateaus. University of Minnesota Press, Minneapolis.

De Souza, H.N., 2006. Sistematizacao da experiencia participativa com sistemas agroflorestais: rumo a sustentabilidade da agricultural familiar na Zona da Mata mineira. Unpublished Msc thesis. Federal University of Vicosa.

De Souza, H., Cardoso, I., Fernandes, J., Garcia, F., Bonfim, V., Santos, A., Carvalho, A., Mendonça, E., 2010. Selection of native trees for intercropping with coffee in the Atlantic Rainforest biome. Agrofor. Syst. 80, 1-16. http://dx.doi.org/10.1007/ s10457-010-9340-9.

Duarte, E., Cardoso, I.M., Stijnen, T., Mendonça, M., Coelho, M., Cantarutti, R., Kuyper, T., Villani, E., Mendonça, E., 2013. Decomposition and nutrient release in leaves of Atlantic Rainforest tree species used in agroforestry systems. Agrofor. Syst. 87, 835-847. http://dx.doi.org/10.1007/s10457-013-9600-6.

Fernandes, E., Cunha, N., Silva, R.G., 2005. Degradação ambiental no estado de Minas Gerais. Rev. Econ. e Soc. Rural 43, 179-198.

Ferrari, L., Carneiro, J., Cardoso, I., Pontes, L., De Sá, E., Lidia, A., Soares, M., 2010. O caso da água que sobe: monitoramento participativo das águas em sistemas agroecológicos. Agriculturas 7, 30-34.

Foster, J.B., 1999. Marx's theory of the metabolic rift: classical foundations for environmental sociology. Am. J. Sociol. 105 (2), 366-405.

Gjorup, D., Souza, H., Bonfim, V., Cardoso, I., Carvalho, A., 2004. Experimentação participativa com sistemas agroflorestais por familiares: histórico. Anais do 20 Congresso Brasileiro de Extenção Universitária, Belo Horizonte.

Gomes, S., 1986. Condicionantes da modernização do pequeno agricultor. IPE/USP (Série Ensaios Econômicos), São Paulo.

Haraway, D.J., 1991. Simians, Cyborgs and Women: the Reinvention of Nature. Routledge, New York.

Hebinck, P., van der Ploeg, J.D., Schneider, S., 2015. Rural Development and the 
Construction of New Markets, Rural Development and the Construction of New Markets. Routledge, London, pp. 1-212.

Hinchliffe, S., 2008. Geographies of Nature: Societies, Environments, Ecologies. Sage publications, London.

Horlings, L., 2016. Connecting people to place: sustainable place-shaping practices as transformative power. Current Opin. Environ. Sustainability 20, 32-40.

IBGE, 2006. Censo Agropecuário 2006. https://cidades.ibge.gov.br/brasil/mg/ araponga/pesquisa/24/27745.

Ingold, T., 1993. The temporality of the landscape. World Archaeol. 25 (2), 152-174.

Jansen, K., 2015. The debate on food sovereignty theory: agrarian capitalism, dispossession and agroecology. J. Peasant Stud. 42, 213-232.

Jasanoff, S. (Ed.), 2004. States of Knowledge: The Co-Production of Science and the Social Order. Routledge.

Latour, B., 1983. Give me a Laboratory and I will raise the world. In: Knorr-Cetina, K., Mulkay, M. (Eds.), Science Observed: Perspectives on the Social Study of Science. Sage Publications Ltd., London, pp. 141-170.

Law, J., 1994. Organizing Modernity. Blackwell, Oxford.

Martins, F., 2007. Taxonomia e etnobotânica de leguminosae adans. em fragmentos florestais e sistemas agroflorestais na Zona da Mata Mineira. Universidade Federal de Viçosa, Viçosa MSc thesis.

Martinez-Alier, J., 2002. The Environmentalism of the Poor: a Study of Ecological Conflicts and Valuation. Edawrd Elgar Publishin, Cheltenham Glos.

Marx, K., 1973. Grundrisse: Foundations of the Critique of Political Economy. Vintage Books, New York.

McFarlane, C., 2009. Translocal assemblages: space, power and social movements. Geoforum 40, 561-567.

McMichael, P., 2015. A comment on Henry Bernstein's way with peasants, and food sovereignty. J. Peasant Stud. 42, 193-204.

McMichael, P., 2013. Food Regimes and Agrarian Questions. Fernwood Publishing, Halifax and Winnipeg.

Mendonça, E., Stott, D., 2003. Characteristics and decomposition rates of pruning residues from a shaded coffee system in Southeastern Brazil. Agrofor. Syst. 57 (2), 117-126.

Moreira, C., 2012. Suppressiveness Mediated by Entomopathogens in Agroforestry and Conventional Soils. Universidade Federal de Viçosa, Viçosa Unpiublished MSc thesis.

Moll, A., 1999. Ontological Politics. A Word and Some Questions. The Sociological Review. pp. 74-90.

Moore, J.W., 2017. The capitalocene, part 1: on the nature and origins of our ecological crisis. J. Peasant Stud. 44 (3), 594-630.

Muller, M., Schurr, C., 2016. Assemblage Thinking and Actor-network Theory: Conjunctions, Disjunctions, Cross-fertilisations. Transactions of the Institute of British Geographershttp://dx.doi.org/10.1111/tran.12117.

Nabuco, M.R., 1990. Brasil e Minas Gerais: modernização e modernidade na agricultura. In: Ensaios Econômicos CEDEPLAR 4. Belo Horizonte. CEDEPLAR, pp. 185-201.

Norgaard, R., 1994. Development Betrayed : the End of Progress and a Coevolutionary Revisioning of the Future. Routledge, London.

Pickering, 2008. New ontologies. In: Pickering, A., Guzik, K. (Eds.), The Mangle in Practice: Science, Society and Becoming. Duke University press, Durham.

Rezende, M., Venzon, M., Perez, A., Cardoso, I., Janssen, A., 2014. Extrafloral nectaries of associated trees can enhance natural pest control. Agric. Ecosyst. Environ. 188, 198-203. http://dx.doi.org/10.1016/j.agee.2014.02.024.

Roep, D., 2000. Vernieuwend werken: sporen van vermogen en onvermogen. Unpublished PhD thesis. Wageningen University, Wageningen.

Roep, D., Wellbrock, W., Horlings, I., 2015. Raising self-efficacy and resilience in the Westerkwartier. The spinoff from collaborative leadership. In: McDonach, J., Nieaber, B., Woods, M. (Eds.), Globalization and Europe's Rural Regions. Ashgate, London, pp. 41-89.

Sabourin, E., 2017. Produção camponesa e seguridade alimentar no Brasil: Uma analise pela teoria da reciprocidade. Revista Latino Americana de Estudios Rurales II, vol. 3. pp. 1-21.

Schneider, M., McMichael, P., 2010. Deepening and repairing the metabolic rift. J. Peasant Stud. 37, 461-484.

Souto, R.L., 2006. Ciclagem de nutrientes em sistemas agroecológicos de produção de café: o uso de leguminosas e plantas espontâneas. Unpublished MSc thesis. Universidade Federal de Viçosa, Viçosa.

Tsing, A., 2000. The global situation. Cult. Anthropology 15, 327-360.
Tsing, A., 2015. Living in Ruins. Capitalism, Blasted Landscapes, and the Possibilities of Life on Earth: a Mushroom Story. Princeton University Press, Princeton.

Turnhout, E., Waterton, C., Neves, K., Buizer, M., 2013. Rethinking biodiversity: from goods and services to 'living with'. Conservation Letters 6 (3), 154-161.

Valverde, O., 1958. Estudo regional da Zona da Mata de Minas Gerais. Rev. Bras. Geogr. 20, 3-79.

Van den Berg, L., Hebinck, P., Roep, D., 2016. 'We go back to the land: processes of repeasantisation in Araponga, Brazil'. J. Peasant Stud. https://doi.org/10.1080/ 03066150.2016.1250746.

Van der Ploeg, J.D., 2013. Peasants and the Art of Farming. A Chayanovian Manifesto. Fernwood Publishers, Halifax. https://doi.org/10.3362/9781780448763.

Van der Ploeg, J.D., 2012. The genesis and further unfolding of farming styles research. Historische Antropologie 20, 417-440.

Van der Ploeg, J.D., Ye, J., Schneider, S., 2012. Rural development through the construction of new, nested, markets: comparative perspectives from China, Brazil and the European Union. J. Peasant Stud. 39 (1), 113-173.

Van der Ploeg, J.D., 2010. The peasantries of the twenty-first century: the commoditisation debate revisited. J. Peasant Stud. 37, 1-30.

Van der Ploeg, J.D., 2017. Differentiation: old controversies, new insights. J. Peasant Stud. 1-36.

Wittman, G., 2009. Reworking the metabolic rift: La via Campesina, agrarian citizenship and food sovereignty. J. Peasant Stud. 36 (4), 805-826.

Woods, M., 2015. Territorialisation and the assemblage of rural place: examples from Canada and New Zealand. In: Dessein, J., Battaglini, E., Horlings, L. (Eds.), Cultural Sustainability and Regional Development: Theories and Practices of Territorialisation. Routledge, London, pp. 29-43.

Leonardo van den Berg is a $\mathrm{PhD}$ candidate at the Forest and Nature Conservation Policy group at Wageningen University and at the Rural Economics Department of the Federal University of Viçosa. His current research is on how agroecology reworks the boundaries between nature, science and society. Leonardo also works for Cultivate! (formerly ILEIA), an independent NGO working on agroecology, is co-founder of Toekomstboeren (La Via Campesina Netherlands) and is member of the coordinating committee of the Dutch Agroecology and Food Sovereignty platform: Voedsel Anders. Email: Leonardo. vandenberg@wur.nl

Dirk Roep is assistant professor and research coordinator at the Rural Sociology Group of Wageningen University and project associate professor at Kyoto University. He has expertise in place-based sustainable agricultural and rural development, sustainable modes of food provisioning, social learning and innovation, transition studies and rural transformation processes. He has a particular interest in place-based food, place-based development, grassroots innovation and institutional reform. He participated in various national and EU-funded research projects since 1999, coordinated a work package in DERREG (Developing Europe's Rural Regions in the Era of Globalization; http://www. derreg.eu/) and SOLINSA (Support of Learning and Innovation Networks for Sustainable Agriculture; http://www.solinsa.net/) and is now coordinating the Marie Currie ITN (Marie Skłodowska-Curie Actions Innovative Training Networks) project SUSPLACE (Sustainable Place-Shaping; http://www.sustainableplaceshaping.net/) exploring the transformative capacity of sustainable place-shaping practices. Email: Dirk.Roep@wur.nl

Paul Hebinck is associate professor in the Sociology of Development and Change group at Wageningen University and adjunct professor at the University of Fort Hare, South Africa. His research interests are at the crossroads of land and agrarian reform and rural livelihoods. He has been engaged since the mid-1990s with longitudinal research in West Kenya, Zimbabwe and South Africa. He edited with Ben Cousins In the shadow of policy. Everyday practices in South African land and agrarian reform (Wits University Press, 2013) and with Jan Douwe van der Ploeg and Sergio Schneider Rural development and the construction of new markets (Routledge, 2015). Email: Paul.Hebinck@wur.nl

Heitor Mancini Teixeira is a sandwich $\mathrm{PhD}$ candidate at the Farming Systems Ecology group at Wageningen University and at the Soils Department of the Federal University of Viçosa. He graduated in Forestry at the Federal University of Viçosa in 2015. His PhD project focuses on the relations between farming, biodiversity and ecosystem services in the Zona da Mata region, Minas Gerais, Brazil. 